\title{
Growth and Yield Parameters of Introduced Oil Palm Crop in Uganda
}

\author{
Gabriel Ddamulira ${ }^{1}$, Alex Asiimwe ${ }^{1}$, Fred Masika ${ }^{1}$, Moses Amugoli ${ }^{1}$, Gerald Ddumba ${ }^{2}$, Alice Nambuya ${ }^{2}$, \\ Patrick Wetaala $^{2} \&$ Mcebisi Maphosa $^{3}$ \\ ${ }^{1}$ National Crops Resources Research Institute, Kampala Uganda \\ ${ }^{2}$ National Coffee Research Institute, Mukono, Uganda \\ ${ }^{3}$ Lupane State University, Bulawayo, Zimbabwe \\ Correspondence: Gabriel Ddamulira, Horticulture and Oil Palm Programme, National Crops Resources Research \\ Institute, P.O. Box 7084, Kampala, Uganda. Tel: 256-774-229-749. E-mail: gdamulira@naro.go.ug
}

Received: May 25, 2020

doi:10.5539/jas.v12n11p299

Accepted: August 4, 2020

URL: https://doi.org/10.5539/jas.v12n11p299

The research is financed by Government of Uganda (GOU) and International Fund for Agricultural Development (IFAD).

\begin{abstract}
Oil palm is commercially grown on Bugala Island within Lake Victoria. But with increasing demand for vegetable oils in Uganda more areas for oil palm production are required. A study was conducted to identify new areas suitable for oil palm production. The experiment was super-imposed on $45 \times 45 \mathrm{~m}$ plots in 3-year old oil palm plantations in Bugiri, Buvuma, Kibaale and Masaka. The experiment was laid out in a randomized complete block design with three replications. From 2011 to 2013 results indicated significant $(\mathrm{P}<0.05)$ mean increments from 98.9 to $141 \mathrm{~cm}$ in height, 166 to $377 \mathrm{~cm}$ in stem girth, 24.3 to 30.1 in number of open leaves and 40.3 to 81.2 in number of flowered palm trees. On the monthly basis the highest fresh fruit bunch (FFB) number and yield were realized in May and October, respectively which corresponded with the peak rain months. Furthermore, significant $(\mathrm{P}<0.05)$ increments of $40.9 \%$ in number of FFB, $55.4 \%$ in bunch weight and $16.9 \%$ in yield were observed from 2014 to 2016. Across sites, Kibaale had the highest (601.5 FFB ha ${ }^{-1}$ ) number of FFB while Masaka registered the lowest number (452.2 FFB ha ${ }^{-1}$ ). Oil palm yield in Kibaale and Buvuma was twice higher than in Masaka. But, yield in Bugiri was not significantly different from that of Buvuma and Kibaale but significantly $(\mathrm{P}<0.05)$ higher than in Masaka. The findings on growth and yield of introduced oil palm crop revealed that Kibale, Buvuma and Bugiri are potential areas for oil palm production in Uganda.
\end{abstract}

Keywords: Elaeis guineensis, plantation, vegetable oil

\section{Introduction}

The oil palm (Elaeis guineensis Jacq.) belongs to Arecoideae sub-family and tribe cocoseae (Dransfield et al., 2005). There are two species of Elaeis, the African (E. guineensis) and American (E. oleifera) oil palms (Corley \& Tinker, 2016). The $E$ guineensis is a large, pinnated-leaved palm having a solitary columnar stem with short internodes (Jacquin, 1763). This specie is widely distributed along the Niger delta (Ghana, Nigeria, Cameroon and Congo) due to environmental and soil conditions that favor its growth. On the other hand, E. Oleifera palms have a short and often procumbent trunk and they mostly flourish in swampy and shady conditions of Brazil, Colombia, Ecuador, Peru, Venezuela, Costa Rica and Honduras (Corley \& Tinker, 2016).

In additional to being grown in its native regions, oil palm is the major oil crop grown worldwide (RSPO, 2013). The crop is a source of vegetable oil yielding about $2.08 \mathrm{t} \mathrm{ha}^{-1}$ more oil when compared to other oil crops (Terzić et al., 2018) and it contributes $31 \%$ of the world's vegetable oils produced (Oil World, 2017). Oil palm originates from West and Central Africa in the belt between Guinea and North Angola (Murphy, 2014). However, due to increasing demand for vegetable oils, oil palm cultivation extended to the equatorial tropics of Africa, South East Asia and Central and South America as secondary centres of production (Corley \& Tinker, 2016). South East Asia is the leading region of oil palm production with Malaysia and Indonesia being top producers in the world with $85 \%$ of the global production (UNDP, 2010). Africa produces 2,537,168 MT of oil palm on 126,858 ha with Nigeria $(1,050,000$ MT) as the leading producer of palm oil in Africa (FAOSTAT, 2018). In Uganda, Kalangala 
district is currently the production hub with 11,484 ha under oil palm cultivation. 6,500 ha belong to the nucleus estate owned by Oil palm Uganda limited and 4,984 ha are under smallholder out-growers (NOPP, 2018).

Oil palm is a reliable source for the much needed vegetable oils in Uganda because yields the highest oil amount per unit area compared to all other vegetable oil crops. Based on this premise in 2001, the Government of Uganda introduced oil palm production with a goal of increasing local vegetable oil production and enhance access to affordable vegetable oil products for Ugandan consumers, as well as providing income sources for smallholder farmers (IFAD, 2012). Commercial oil palm planting started in 2005 targeting 10,000 hectares of land on Bugala Island, in Kalangala district (MAAIF, 2016). Later on, it was realized that the targeted 10,000 ha would not meet the domestic vegetable oil demand of 240,000 metric tonnes, hence an additional 1,484 ha were put under oil palm production. However with the additional hectares further expansion on the island was not possible because the island had reached its ecological potential in terms oil palm trees that can be sustainably grown without interfering with the environment. Due to shortage of land for more oil palm production on the island, new areas outside the island needed to be identified for further oil palm cultivation. Similarly, the successful production of oil palm on Bugala island proved the benefits of the crop and formed a basis for expansion of oil production to other suitable areas country wide (NOPP, 2018).

Bugiri Buvuma, Masaka and Kibaale are among the areas with prospects for oil palm growing because of their proximity to lakes Victoria and Albert, just like Bugala Island but growth and yield performance oil palm in these areas remained unknown. However, since oil palm growth and yield depends on a number of factors like differences in environmental and soil conditions, yet available soil moisture differ depending on geographical locations (Carr, 2011; Henson \& Harun, 2005). It was hypothesized that growth and yield performance of oil palm in Bugiri, Buvuma, Masaka and Kibaale varied depending on location. Therefore evaluation trials were conducted to generated information needed to confirm this variation and identify suitable areas for future oil palm production.

\section{Materials and Methods}

\subsection{Study Sites}

The experiment was conducted for six years from 2010 to 2016 in two agro-ecological zones: Lake Victoria Crescent and Lake Albert Crescent and western highlands, and four sites: Buvuma, Bugiri, Kibaale and Masaka, in Uganda. The details of the climatic conditions of the study sites are provided in Table 1. The four study sites receive bi-modal rainfall patterns with the first rain season occurring from March to May and second from August to November. However, Buvuma being an island the dry seasons are mild with some rainfall being received but during the dry season the other are dry with no rain.

Table 1. Climatic conditions for the study sites where the experiments were conducted in Uganda

\begin{tabular}{llllll}
\hline \multirow{2}{*}{ Agro-ecological zones } & \multirow{2}{*}{ Study sites } & \multirow{2}{*}{ Altitude (M) } & \multirow{2}{*}{ Annual Rainfall (mm) } & \multicolumn{2}{c}{ Temperature $\left({ }^{\mathbf{0}} \mathbf{C}\right)$} \\
\cline { 5 - 6 } & & & & Minimum & Maximum \\
\hline \multirow{2}{*}{ Lake Victoria Crescent } & Buvuma & 1340 & 1363 & 19.0 & 28.0 \\
& Bugiri & 1080 & 1150 & 16.7 & 30.6 \\
\cline { 4 - 6 } Lake Albert Crescent \& western highlands & Masaka & 1288 & 1250 & 15.0 & 30.0 \\
\hline
\end{tabular}

\subsection{Soil Nutrient Analysis}

Before superimposing the experiment on the existing 3-year old oil fields, soil nutrient status of the oil palm fields in the four sites was examined through random collection of 10 soil samples at a soil depth of $0-60 \mathrm{~cm}$. The samples were composited into five samples and taken to the laboratory for analysis. The composite soil samples were air-dried, ground and passed through a 2-mm sieve and prepared for routine analysis of texture, $\mathrm{pH}$, organic matter $(\mathrm{OM})$, total nitrogen $(\mathrm{N})$, exchangeable calcium $(\mathrm{Ca})$, magnesium $(\mathrm{Mg})$ and potassium $(\mathrm{K})$, available phosphorus $(\mathrm{P})$ and nitrates in triplicates. The texture was determined by hydrometer method and soil $\mathrm{pH}$ was measured using glass electrode method with a soil-to-water ratio of 1:2.5. Soil total $\mathrm{N}$ was determined by micro-Kjeldahl method (Anderson \& Ingram, 1993). Available soil P was extracted using Olsen's method (Olsen \& Sommers, 1982). Exchangeable $\mathrm{Ca}$ and $\mathrm{Mg}$ were determined by an atomic spectrophotometer and $\mathrm{K}$ by a flame photometer (Okalebo, 2002). 
Table 2. Soil physical-chemical properties at the four study sites

\begin{tabular}{lllllllll}
\hline Sites & $\mathbf{p H}$ & $\mathbf{O M}(\mathbf{\%})$ & $\mathbf{N}(\mathbf{\%})$ & $\mathbf{P}(\mathbf{m g} / \mathbf{k g})$ & $\mathbf{K}(\mathbf{m g} / \mathbf{k g})$ & $\mathbf{C a}(\mathbf{m g} / \mathbf{k g})$ & $\mathbf{M g}(\mathbf{m g} / \mathbf{k g})$ & Texture \\
\hline Bugiri & 6.5 & 1.60 & 0.18 & 8.1 & 9.2 & 3367.8 & 1655.3 & Sandy clay loam \\
Buvuma & 5.5 & 2.30 & 0.21 & 12.5 & 68.8 & 1583.7 & 314.0 & Sandy clay \\
Kibaale & 5.8 & 2.60 & 0.24 & 2.3 & 29.9 & 1638.9 & 695.1 & Sandy clay loam \\
Masaka & 6.0 & 2.90 & 0.22 & 9.3 & 39.7 & 1593.6 & 289.2 & Clay \\
Critical values & $\mathbf{5 . 2}^{*}$ & $\mathbf{3 . 0 0}^{*}$ & $\mathbf{0 . 2 0}$ & $\mathbf{2 5 *}$ & $\mathbf{7 8 . 2}^{*}$ & $\mathbf{1 5 0}^{*}$ & $\mathbf{1 8}^{*}$ & \\
\hline
\end{tabular}

Note. ${ }^{*}$ The values below the critical value means the soil parameter is deficient (Foster, 1971).

\subsection{Experimental Design}

The experiment was superimposed on some of the six oil palm adaptive trial fields which were established across the country in 2008. The four study sites (Buvuma, Bugiri, Kibaale and Masaka) were randomly selected from the six adaptive trials using Genstat software. The three year old fields used in the study hand been planted with cold tolerant oil palm hybrids (TAN $\times$ AVROS: a cross between materials planted in the Dura and Pisifera lines) which were acquired from Nigeria. Within the fields the experiments was set up on $(45 \times 45) \mathrm{m}$ plots which were laid out in a Randomized Complete Block Design (RCBD) with three replications at the time of planting in 2008. The oil palm trees in the experimental plots were triangularly spaced at $9 \times 9 \mathrm{~m}$ as recommended

\subsection{Crop Management}

At the time of field establishment in 2008, NPK fertilizer was applied in the ratios 13-8-27+0.5 Boron $250 \mathrm{~g}$ per tree. But during the experimentation period (2010-2016), fertilizer was not applied to depict the farmer's low input cropping system which does not use inorganic fertilizers. Weeds were regularly controlled at an interval of 3 months by ring weeding around the tree palm. Pruning was done twice per year, at the beginning of the main harvesting seasons (March and September) and at the end of the harvesting seasons (June and December). In addition, minimal pruning was regularly carried out during the course of harvesting.

\subsection{Data Collection and Analysis}

Data on the following growth and yield parameters; height, stem girth, number of fruit bunch; bunch weight and yield were collected at different stages of tree development. Growth data (height and stem girth) was collected for three years $(2011,2012$ and 2013). But at flower initiation in fourth year, growth data collection was discontinued and yield data collection started within the same plots for three years (2014, 2015 and 2016). The height was measured annually from the tree base (ground level) upwards to the base of spear leaves. Similarly, stem girth was measured annually by tying a measuring tape around the tree stem at one foot from the ground to take the circumference. The fruit bunch number and yield data were recorded by harvesting bunches at intervals of 10 days, the number of fresh fruit bunches were counted and weighted individually using a weighing scale. The cumulative yield per month was computed to generate yield per year. In order to assess the difference in data collected between years a homogeneity test was performed according to Cochran's test and the test revealed significant $(\mathrm{P}<0.05)$ differences among the years. In additional, Kurtosis-Skew test was conducted on data prior to analysis and found it normally distributed. Then analysis of Variance (ANOVA) was performed for all parameters with the statistical analysis using Genstat version 11 (Payne 2011). Significant means were separated using Least Significant Difference (LSD) at $\alpha<0.05$.

\section{Results}

\subsection{Oil Palm Growth}

In terms of years, plant height averagely increased from 62.2 to $141 \mathrm{~cm}$ across the three years (Table 2). Masaka had the highest palm height followed by Buvuma and Bugiri registered the lowest height (Table 3). Average stem girth also increased from 109 to $252 \mathrm{~cm}$ from 2011 to 2013 with Bugiri registering the biggest stem girth and Kibaale the smallest. On the other hand stem girth across study sites did not significantly differ. 
Table 3. Oil palm height and stem girth from 2011 to 2013 at four sites in Uganda

\begin{tabular}{llllllll}
\hline \multirow{2}{*}{ Location } & \multicolumn{3}{c}{ Plant height (cm) } & & \multicolumn{3}{c}{ Stem girth (cm) } \\
\cline { 2 - 3 } \cline { 6 - 8 } & $\mathbf{2 0 1 1}$ & $\mathbf{2 0 1 2}$ & $\mathbf{2 0 1 3}$ & & $\mathbf{2 0 1 1}$ & $\mathbf{2 0 1 2}$ & $\mathbf{2 0 1 3}$ \\
\hline Bugiri & $40.0^{\mathrm{a}}$ & $70.5^{\mathrm{a}}$ & $89.5^{\mathrm{a}}$ & & $85^{\mathrm{a}}$ & $135^{\mathrm{a}}$ & $280^{\mathrm{a}}$ \\
Buvuma & $61.5^{\mathrm{b}}$ & $105.0^{\mathrm{b}}$ & $145.0^{\mathrm{b}}$ & & $80^{\mathrm{a}}$ & $160^{\mathrm{b}}$ & $220^{\mathrm{b}}$ \\
Kibaale & $42.5^{\mathrm{a}}$ & $79.0^{\mathrm{a}}$ & $120.0^{\mathrm{c}}$ & & $75^{\mathrm{a}}$ & $115^{\mathrm{c}}$ & $213^{\mathrm{b}}$ \\
Masaka & $105.0_{\mathrm{c}}$ & $141.0^{\mathrm{c}}$ & $177.0^{\mathrm{d}}$ & & $198^{\mathrm{b}}$ & $256^{\mathrm{c}}$ & $298^{\mathrm{a}}$ \\
Mean & 62.2 & 98.9 & 141.0 & & 109 & 166 & 252 \\
\hline
\end{tabular}

Note. Plant height and stem girth means followed by different letters in a column are significantly different and means followed by a similar letter are not significantly different.

The number of open leaves and flowered trees of oil palm increased from 2011 to 2013 (Table 4). Among the sites in 2013, palm trees at Masaka were observed to have the highest number of open leaves and flowers trees. On the other hand, the lowest number of palm trees with opened leaves and flowers were registered in Bugiri (Table 4).

Table 4. Number of oil palm open leaves and flowered trees from 2011 to 2013 at four study sites in Uganda

\begin{tabular}{llllllll}
\hline \multirow{2}{*}{ Location } & \multicolumn{3}{c}{ Number of open leaves } & & \multicolumn{3}{c}{ Number of flowered trees } \\
\cline { 2 - 3 } \cline { 6 - 8 } & $\mathbf{2 0 1 1}$ & $\mathbf{2 0 1 2}$ & $\mathbf{2 0 1 3}$ & & $\mathbf{2 0 1 1}$ & $\mathbf{2 0 1 2}$ & $\mathbf{2 0 1 3}$ \\
\hline Bugiri & $9.5^{\mathrm{a}}$ & $22.0^{\mathrm{a}}$ & $21.5^{\mathrm{a}}$ & & $13.0^{\mathrm{a}}$ & $59.0^{\mathrm{a}}$ & $69.5^{\mathrm{a}}$ \\
Buvuma & $19.0^{\mathrm{b}}$ & $28.0^{\mathrm{b}}$ & $29.5^{\mathrm{b}}$ & & $30.0^{\mathrm{b}}$ & $60.0^{\mathrm{a}}$ & $77.5^{\mathrm{b}}$ \\
Kibaale & $8.5^{\mathrm{a}}$ & $16.0^{\mathrm{c}}$ & $31.0^{\mathrm{b}}$ & & $7.5^{\mathrm{c}}$ & $40.0^{\mathrm{b}}$ & $80.5^{\mathrm{b}}$ \\
Masaka & $25.5^{\mathrm{c}}$ & $31.5^{\mathrm{b}}$ & $38.5 \mathrm{c}$ & & $81.5^{\mathrm{d}}$ & $81.5^{\mathrm{c}}$ & $97.5^{\mathrm{c}}$ \\
Mean & 15.6 & 24.3 & 30.1 & & 31.2 & 60.1 & 81.2 \\
\hline
\end{tabular}

Note. Mean number of open leaves and flowered trees followed by different letters in a column are significantly different and means followed by a similar letter are not significantly different.

\subsection{Mean Monthly Variation of Oil Palm Bunch Numbers and Yield}

Monthly the number of fruit bunches and yield varied significantly $(\mathrm{P}<0.05)$ while across sites no significant difference was observed. Two peaks for oil palm bunch and yield were observed in the months of May and October respectively, whereas the lowest number of fruit bunch numbers and yield were recorded during the months of December and February (Figures 1 and 2).

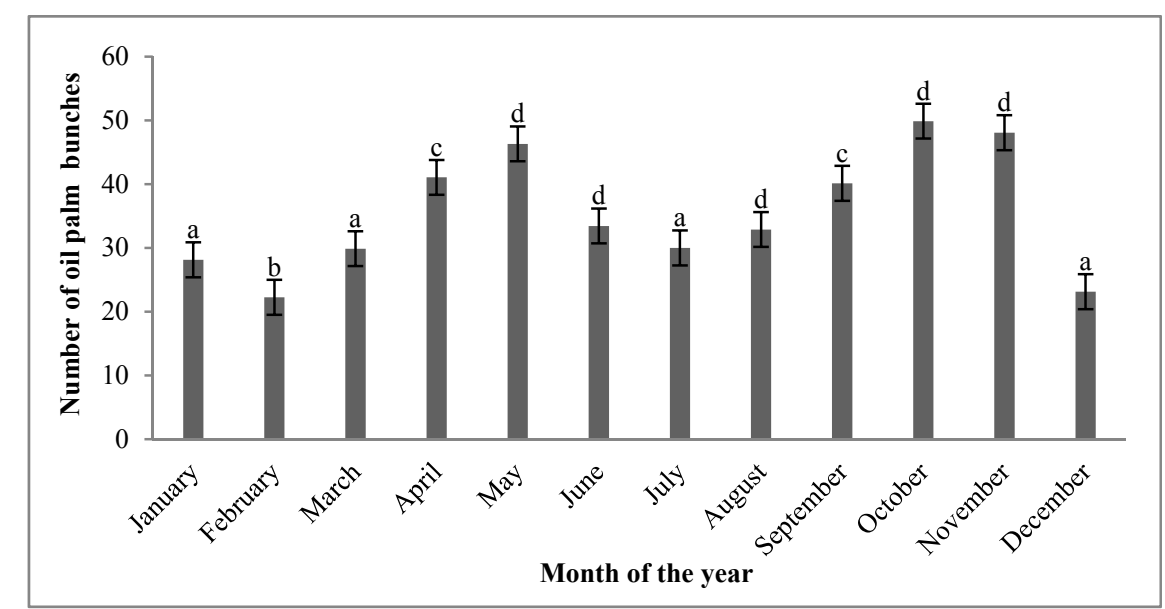

Figure 1. Mean fresh fruit bunches harvested in a month over a period of one year: Mean fresh fruit bunch followed by different letters across bars are significantly different and means followed by similar letters are not significantly different; vertical bars on the graph are error bars 


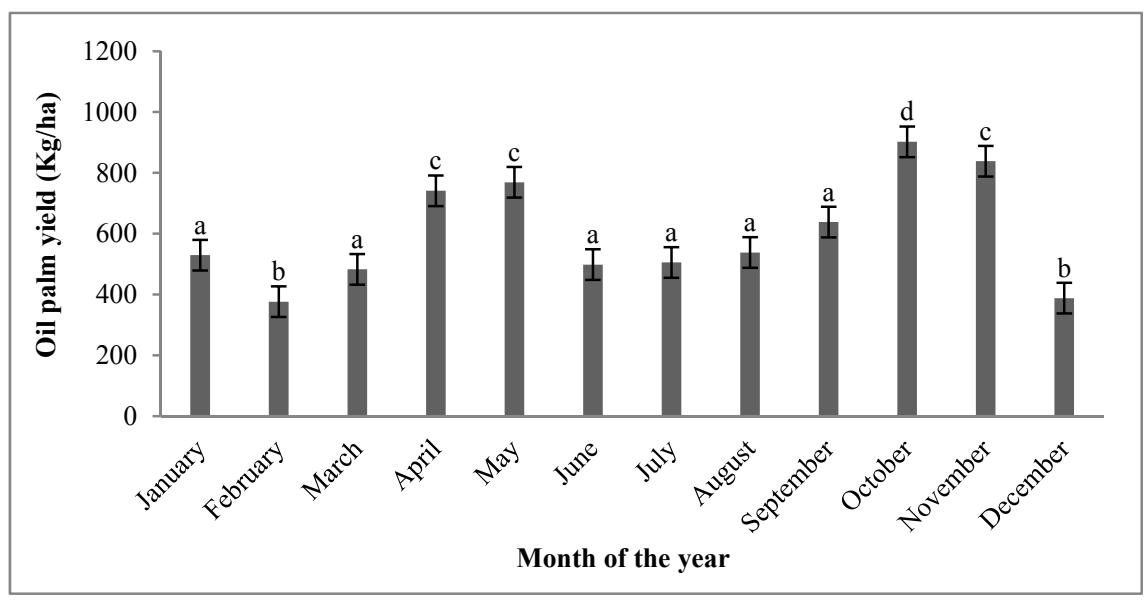

Figure 2. Mean oil palm yield harvested in a month over a period of one year: Mean yield followed by different letters across bars are significantly different and means followed by similar letters are not significantly different; vertical bars on the graph are error bars

Yield components are critical in determining the actual yield of oil palm. Based on the analysis of variance a significant $(\mathrm{P}<0.05)$ difference in fruit bunch number, weight and yield were observed across years. The highest number of fruit bunches were recorded in 2016 and the least in 2014. In the same way bunch weight and yield in 2016 was higher than those realized in 2014 and 2016 (Table 5)

Table 5. Mean yield components of oil palm for three consecutive years in Uganda

\begin{tabular}{llll}
\hline Years & Number of bunches/ha & Bunch weight $\mathbf{( K g )}$ & Yield Kg/ha/year \\
\hline 2014 & $454^{\mathrm{a}}$ & $9.71^{\mathrm{a}}$ & $5455^{\mathrm{a}}$ \\
2015 & $545^{\mathrm{a}}$ & $10.60^{\mathrm{a}}$ & $6165^{\mathrm{a}}$ \\
2016 & $768^{\mathrm{b}}$ & $16.48^{\mathrm{b}}$ & $7212^{\mathrm{b}}$ \\
$\mathrm{Cv} \%$ & 18.1 & 15.6 & 23.4
\end{tabular}

Note. Yield component means followed by different letters in a column are significantly different and means followed by similar letters are not significantly different; CV: Cofficient of varation.

The number of fruit bunches harvested across sites differed significantly $(\mathrm{P}<0.05)$ except for Bugiri and Buvuma. Kibaale registered the highest number of bunches while Masaka had the least number of bunches (Table 6). But for the case of fruit bunch weight, no significant difference was observed across Bugiri, Buvuma and Kibaale. However, the bunch weight at Masaka which was lowest was significantly different from the rest of the sites. Similarly, oil palm yield did not significantly vary among Bugiri, Buvuma and Kibaale, except Masaka where the lowest yield was recorded (Table 6).

Table 6. Mean yield components of oil palm across four study sites in Uganda

\begin{tabular}{llll}
\hline \multirow{2}{*}{ Sites } & \multicolumn{3}{c}{ Yield components } \\
\cline { 2 - 4 } & No. bunches/ha & Bunch weight $(\mathbf{K g})$ & Yield kg/ha/year \\
\hline Bugiri & $525.0^{\mathrm{a}}$ & $12.51^{\mathrm{a}}$ & $6560.6^{\mathrm{a}}$ \\
Buvuma & $527.4^{\mathrm{a}}$ & $15.15^{\mathrm{a}}$ & $7480.0^{\mathrm{a}}$ \\
Kibaale & $601.5^{\mathrm{b}}$ & $13.41^{\mathrm{a}}$ & $7462.3^{\mathrm{a}}$ \\
Masaka & $452.2^{\mathrm{c}}$ & $7.86^{\mathrm{b}}$ & $3607.3^{\mathrm{b}}$ \\
Cv (\%) & 19.7 & 11.2 & 17.3 \\
\hline
\end{tabular}

Note. Yield component means followed by different letters in a column are significantly different and means followed by similar letters are not significantly different; CV; Coefficient of variation. 


\section{Discussion}

In common with other palms, oil palm growth involves several processes like phytomer production which contribute directly to plant height. The increase in oil palm height observed in Table 3 could be attributed to physiological processes like phytomer production that occur during vegetative growth phase. During this phase, addition of stem segments associated with apical production of new phytomers takes places. The new phytomers produced at the stem top are responsible for stem elongations which increase plant height (Legros et al., 2009). Nonetheless, the variation in palm height observed across study sites was attributed to differences in environmental conditions. Environmental conditions such as rainfall, sunlight and temperature (Table 1) were different across study sites. The variation in rainfall, sunlight and temperature influence carbohydrate reserve storage or mobilization which is known to affect production of new phytomers. Hence, the variation in environmental conditions partly explained the difference in oil palm plant height observed across the four study areas. Although oil palm height differed across study sites as observed in Table 3 but stem girth did not significantly vary because oil palm stems have no secondary growth during the early vegetative phase, which contributes to their constant stem diameter (Gordon \& Dejong, 2007). The lack of variation in stem girth observed was further explained by the fact that the same oil palm hybrids with similar genetic make-up were planted in all the study sites, hence very little or no variation in stem girth was expected from palms of the similar genetic-make up.

In oil palm growth cycle, flowering is usually determined during vegetative growth and the amount of rainfall received in a particular location. According to Woittiez et al. 2017 leaf initiation determines the potential number of inflorescences because a single inflorescence is initiated in the axil of each leaf. This phenomena explained the results in Table 4 which revealed an increase in the number of open leaves which corresponded with increase in palm trees with inflorescences from 2011 to 2013. On the other hand, the high number of opened leaves and flowered trees observed at Masaka (Table 4) which ranged between 25 to 35 leaves per year at six years after planting was expected for a location that receives sufficient rainfall (Table 1) as earlier reported by Gerritsma and Soebagyo (1999). However, the low number of oil palm opened leaves and flowered trees at Bugiri could be attributed to low rainfall associated with drought that cause water stress conditions to the palms. Among the study sites, Bugiri received the least amount of rain yet the rate of leaf opening in palms is reduced rapidly in response to water stress, resulting in accumulation of unopened leaves in the centre of the crown (Nouv et al., 1999). The same author has also reported that drought conditions reduce on the number of inflorescence which also explained the low number of flowered trees in Bugiri as compared to other sites in the study which receives more rainfall and experienced less of the water stress.

As water is critical in leaf opening and flowering it is also equally important in fruit bunch and yield formation. In this study the influence of water on fruit bunch and yield was exhibited by monthly variation in fruit bunch and yield in Figures 1 and 2. High fruit bunch and yield were observed during the rain peak months of May and October and the least fruit bunch and yield were recorded in December and February which are both dry months. This was attributed to the fact that during rainy season less transpiration occur causing less of water stress while during the dry season more transpiration occurs leading to moisture stress which retard bunch number and yield. Similarly results have been reported in Malaysia where oil palm fruit bunch and yield was reduced due to high evaporation rate experienced during the dry season (Henson \& Chang, 1990). On average evaporation rates of 4.0-6.5 mm day ${ }^{-1}$ in the dry season and 1.0-2.5 mm day ${ }^{-1}$ on rainy days have been recorded in oil palm plantations (Carr, 2011).

On the other hand, the increase in number of fruit bunches, weight and yield from 2016-2018 in Table 5 was possibly attributed to the fact that the palm trees tested were in their young mature phase or 'steep ascent yield phase'(4-7 years after planting). During this growth phase, bunch number, weight and yield increase linearly as earlier reported by Rao et al. (2008). This was clearly exhibited in the results obtained between 2016-2018. In this study oil palm yield increased linearly in the steep ascent yield phase but the yield obtained was less $(7.2 \mathrm{t}$ $\mathrm{ha}^{-1} \mathrm{yr}^{-1}$ ) than 10-15 $\mathrm{tha}^{-1} \mathrm{yr}^{-1}$ earlier reported by Fairhurst and Griffiths (2014) for the same phase. This meant that $t$ oil palm introduced in Uganda yielded less compared to their place of origin for the same phase.

Furthermore, the variation in bunch number, weight and yield across study sites in Table 6 was due to differences in soil properties across sites. Among the study sites, it was only Masaka which had soil with clay texture (Table 2). Because of the clayish nature of the soil at Masaka, the site was prone to water logging during the rainy season which could have compromised soil aeration and nutrient uptake. Although not quantified but yield losses due to growing oil palm in clay soils that are prone to water logging has been recorded in Asia (Paramananthan, 2013). Nonetheless, oil palm is tolerant to temporary flooding because of the ability of its roots to form pneumatodes (Jourdan \& Rey, 1997). However, if roots are submerged they are unable to respire normally, 
leading to impaired water and nutrient uptake, delayed frond opening, and reduced carbohydrate availability (Corley \& Tinker, 2016). Henson et al. (2008) also demonstrated that photosynthetic activity and transpiration rates are 3-4 times less in oil palms under waterlogged conditions compared with palms in well-drained soils. Therefore the impaired water and nutrient uptake as a result of clay soils which encourage water logging, possibly reduced bunch weight and yield in Masaka as compared to other three sites with well drained soils.

Based on the study findings, Bugiri, Buvuma, Kibaale have growth conditions that can support large oil palm growth in Uganda as longer as proper management practices to enhance yield are used. On the other hand, to support optimal oil palm growth in Masaka requires management practices that can improve soil texture.

\section{Acknowledgements}

We acknowledge the Ministry of Agriculture Animal Industry and Fisheries (MAAIF) through the Vegetable Oil Development Project (VODP) and the International Fund for Agricultural Development (IFAD) for providing research funds and NARO for facilitating research activities.

\section{Reference}

Anderson, J. M., \& Ingram, S. J. (1993). Tropical soil biology and fertility: A handbook of methods. CAB International, Wallingford, UK. https://doi.org/10.1097/00010694-199404000-00012

Carr, M. K. V. (2011). The water relations and irrigation requirement of oil palm (Elaeis guineensis): A review. Exp. Agric., 47(4), 629-652. https://doi.org/10.1017/s0014479711000494

Corley, R. H. V. (2009). How much palm oil do we need? Environ. Sci. Policy, 12, 134-139. https://doi.org/ 10.1016/j.envsci.2008.10.011

Corley, R. H. V., \& Tinker, P. B. (2016). The Oil Palm. John Wiley \& Sons, New York. https://doi.org/10.1002/ 9781118953297

Denis, J. M. (2014). The future of oil palm as a major global crop: Opportunities and challenges. Journal of Oil Palm Research, 26(1), 1-24.

Dransfield, J. N. W., Rasmussen, C. B., Baker, W. J., Harley, M. M., \& Lewis, C. E. (2005). A new phylogenetic classification of the palm family Arecaeceae. Kew Bull, 60, 559-569.

Fairhurst, T., \& Griffiths, W. (2014). Oil Palm: Best Management Practices for Yield Intensification (p. 180). International Plant Nutrition Institute and Tropical Crop Consultants Limited, Penang, Malaysia.

Food and Agriculture Organization of the United Nations. (2018). FAOSTAT Statistical Database. FAO Publications, Rome, Italy.

Foster, H. L. (1971). Rapid routine soil and plant analysis without automatic equipment, routine soil analysis. East African Agriculture and Forest Journal, 37, 160-170. https://doi.org/10.1080/00128325.1971. 11662519

Gerritsma, W., \& Soebagyo, F. X. (1999). An analysis of the growth of leaf area of oil palms in Indonesia. Exp. Agric., 35(3), 293-308. https://doi.org/10.1017/S0014479799003038

Gordon, D., \& Dejong, T. M. (2007). Current-year and subsequent-year effects of crop-load manipulation and epicormic-shoot removal on distribution of long, short and epicormic shoot growth in Prunus persica. Annals of Botany, 99, 323-332. https://doi.org/10.1093/aob/mcl262

Henson, I. E, \& Harun, M. H. (2005). The influence of climatic conditions on gas and energy exchanges above a young oil palm stand in North Kedah. Malaysia J. Oil Palm Res., 17, 73-91.

Henson, I. E., \& Chang, K. C. (1990). Evidence for water as a factor limiting performance on field palms in West Malaysia (pp. 487-498). Proceedings of the PORIM International Palm Oil Development Conference: Module II-Agriculture, September 5-9, 1989, Palm Oil Research Institute of Malaysia, Kuala Lumpur.

Henson, I. E., Harun, M. H., \& Chang, K. C. (2008). Some observations on the effects of high water tables and flooding on oil palm, and a preliminary model of oil palm water balance and use in the presence of a high water table. Oil Palm Bull, 56, 14-22.

IFAD. (2012). Republic of Uganda Vegetable Oil Development Project-Phase 2 (VODP2). Supervision and Implementation Support Mission Report, December 3-14, 2012, Report No. 2841. IFAD, Rome.

Jacquin, N. J. (1763). Selectarum stirpium Americanarum historia. Smithsonian Libraries. https://doi.org/ 10.5962/bhl.title. 113426 
Jourdan, C., \& Rey, H. (1997). Architecture and development of the oil-palm (Elaeis guineensis Jacq.) root system. Plant Soil, 189(1), 33-48. https://doi.org/10.1023/A:1004290024473

Legros, S., Mialet-Serra, I., Caliman, J. P., Siregar, F. A., Clement-Vidal, A. D., Fabre, D., \& Dingkuhn, M. (2009). Phenology, growth and physiological adjustments of oil palm (Elaeis guineensis) to sink limitation induced by fruit pruning. Annals of Botany, 104, 1183-1194. https://doi.org/10.1093/aob/mcp216

Lotte, S. W., Wijkb, M. T. V., Slingerlanda, M., Noordwijka, M. V., Ken, C., \& Giller, E. (2017). Yield gaps in oil palm: A quantitative review of contributing factors. Europ. J. Agronomy, 83, 57-77. https://doi.org/10.1016/ j.eja.2016.11.002

MAAIF. (2016). Agriculture Sector Strategic Plan 2015/16-2019/20. Ministry of Agriculture, Animal Industries and Fisheries, Kampala, Republic of Uganda.

Murphy, D. J. (2014). The future of oil palm as a major global crop: opportunities and challenges. Journal of Oil Palm Research, 26(1), 1-24.

NOPP. (2018). Republic of Uganda National Oil Palm Project.

Nouy, B., Baudouin, L., Djegui, N., \& Omore, A. (1999). Le palmier à huile en conditions hydriques limitantes. Plant. Recherche Dév, 6, 31-45.

Okalebo, J. R., Gathua, K. W., \& Woomer, P. L. (2002). Laboratory methods of soil and plant analysis: A working manual (2nd ed.). TSBF-CIAT and SACRED Africa, Nairobi, Kenya.

Olsen, S. R., \& Sommers, L. E. (1982). Determination of available phosphorus. In A. L. Page, R. H. Miller, \& D. R. Keeney (Eds.), Method of Soil Analysis (Vol. 2). Madison, WI: American Society of Agronomy.

Paramananthan, S. (2013). Managing marginal soils for sustainable growth of oil palms in the tropics. J. Oil Palm Environ, 4, 1-16. https://doi.org/10.5366/jope.2013.1

Payne, R. W., Murray, D. A., Harding, S. A., Baird, D. B., \& Soutar, D. M. (2011). GenStat for Windows (14th ed.). VSN International, Hemel.

Rao, V., Palat, T., Chayawat, N., \& Corley, R. H. V. (2008). The Univanich oil palm breeding programme and progeny trial results from Thailand. Planter, 84(989), 519-531.

RSPO (Roundtable on Sustainable Palm Oil). (2013). RSPO concessions.

Ssemmanda, R., \& Opige, M. (2019). An assessment of the impacts of oil palm in Kalangala and Buvuma. Lessons learned and recommendations for future developments. Wageningen, the Netherlands: Tropenbos International and Ecological Trends Alliance.

UNDP. (2010). Palm oil scoping paper (p. 38). Internal working document. Green commodities Facility.

\section{Copyrights}

Copyright for this article is retained by the author(s), with first publication rights granted to the journal.

This is an open-access article distributed under the terms and conditions of the Creative Commons Attribution license (http://creativecommons.org/licenses/by/4.0/). 